\title{
Framing national REDD+ benefits, monitoring, governance and finance: A comparative analysis of seven countries
}

Marjanneke J. Vijge ${ }^{\mathrm{a}^{*}}$, Maria Brockhaus ${ }^{\mathrm{b}}$, Monica Di Gregorio ${ }^{\mathrm{b}, \mathrm{c}}$, Efrian Muharrom $^{\mathrm{b}}$

17 January 2016

Prepared for resubmission to Global Environmental Change

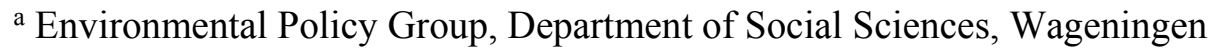

University \& Research Centre, Hollandseweg 1, 6706 KN Wageningen, The

Netherlands.

${ }^{\mathrm{b}}$ Center for International Forestry Research, P.O. Box 0113 BOCBD, Bogor 16000,

Indonesia

${ }^{\mathrm{c}}$ University of Leeds, School of Earth and Environment, Sustainability Research

Institute, Leeds, LS 29JT, United Kingdom

\section{Acknowledgements:}

This research is part of the policy component of CIFOR's Global Comparative Study on REDD+ (www.cifor.org/gcs). The methods applied in this study build partially on research undertaken by the Comparing Climate Change Policy Networks program (www.compon.org), led by Jeffrey Broadbent and funded by the National Science Foundation. The authors would like to express their deep gratitude to our partners and the individual country teams in the Global Comparative Study, without whose work in the research countries this article would not have been possible. Sofi Mardiah, Cynthia Maharani, Bimo Dwisatrio and Christine Wairata played highly valuable roles in research support and editing. Funding for CIFOR's research was provided by the Norwegian Agency for Development Cooperation, the Australian Agency for International Development, the UK Department for International Development, and the European Commission. In addition, travel funding for one of the authors was provided from Wageningen School of Social Sciences. Finally, we would like to thank Aarti Gupta for providing advice on the research design for the article.

\footnotetext{
* Corresponding author. E-mail: marjanneke.vijge@gmail.com. Tel.: $+31(0) 610810191$.
} 


\title{
17 January 2016
}

Prepared for resubmission to Global Environmental Change

Word count: 8,128 (excluding references, including tables and figure captions)

\begin{abstract}
This article analyzes how and with what possible consequences REDD + is framed in the national policy arena in Cameroon, Indonesia, Nepal, Papua New Guinea, Peru, Tanzania, and Vietnam. It analyzes the most prominent views and storylines around key REDD+ design features among policy actors and in policy documents. We focus on storylines related to four questions, namely: 1) What should REDD+ achieve: carbon or also non-carbon objectives? 2) Who should monitor REDD+ outcomes: only technical experts or also local communities? 3) At what level should REDD+ be governed: at national or sub-national level? and 4) How should REDD+ be financed: through market- or fund-based sources? The vast majority of policy actors and policy documents frame REDD+ as a mechanism that should also realize non-carbon benefits, yet non-carbon monitoring receives very little attention. In all but one country, policy documents contain plans to involve local communities in the design and/or execution of measuring, reporting and verifying REDD+ outcomes. With regard to the level at which REDD+ should be governed, while most policy documents contain elements of a nested approach to accounting, almost all countries envision a long-term transition to national accounting and benefit distribution. We found strikingly little discussion among policy actors and in policy documents of how to finance REDD+ and acquire results-based payments. In the conclusion we reflect on possible consequences of the prominence of REDD+ storylines in the seven countries, and argue that carbonization and centralization of forest governance are possible given the limited attention to non-carbon monitoring and the envisioned centralized approaches to REDD+.
\end{abstract}

Key words: REDD+; Comparative discourse analysis; Co-benefits; Market-based approach; MRV; Centralization. 


\section{Introduction}

Though Reducing Emissions from Deforestation and Forest Degradation and the role of conservation, sustainable management of forests and enhancement of forest carbon stocks (REDD+) is arguably one of the most advanced climate mitigation options, scholars and politicians are still debating and negotiating important aspects of its design, both within and outside the United Nations Framework Convention on Climate Change (UNFCCC). A variety of state and non-state actors are operationalizing REDD+ policies and practices at the global, national and project level based on a diversity of ideas of what constitutes REDD+. A large and growing body of literature aims to assess the progress in REDD+ policy development and implementation and the (possible) consequences (see e.g. Angelsen et al., 2009, 2012; Gupta et al., 2013; Levin et al., 2008). Much less literature analyzes the discourses of actors involved in REDD+, such as what REDD+ should achieve and how it should be operationalized. Discourse analyses are useful to describe or explain how certain ideas gain prominence over others and become institutionalized. They can provide important insight into the direction that a certain policy instrument such as REDD+ is likely to take, and what possible consequences this might have. Most of the existing REDD+ discourse analyses focus on the global REDD+ domain (Den Besten et al., 2014; Hiraldo and Tanner, 2011). Only a few have investigated such discourses at the national level, and very few have done so comparatively (Pistorius et al., 2012; Di Gregorio et al., 2015; Van der Hoff et al., 2015).

This article contributes to this small but growing body of literature by carrying out a cross-country comparative analysis of how REDD+ is framed among national policy actors and in national policy documents in Cameroon, Indonesia, Nepal, Papua New Guinea (PNG), Peru, Tanzania, and Vietnam. We focus on four key policy design features that have prominence in current scholarly and political debates and that determine the long-term effectiveness and equity of REDD+ (Vijge, 2015; Gupta et al., 2012; Visseren-Hamakers et al., 2012a, b; Angelsen et al., 2009, 2012). These can be expressed as four questions: 1) What should REDD+ achieve? 2) Who should monitor REDD+ outcomes? 3) At what level should REDD+ be governed? and 4) How should REDD+ be financed? Answers to these questions represent design options for REDD + that are currently under consideration. Which options become prominent will affect what benefits REDD+ will generate and for whom, who has the power to monitor and govern REDD+, and who will bear the financial costs. Our aim is to analyze how debates around the four questions resonate in the national policy arenas of the seven countries, and draw implications for their national forest governance. We do so by assessing which views around these questions are prominent among national policy actors, and which storylines are reflected in the countries' Readiness Preparation Proposals (R-PPs), the REDD+ plans that are prepared as part of the World Bank's Forest Carbon Partnership Facility program.

The next section presents the analytical framework related to the REDD+ storylines. Section 3 explains how discourse analysis is used to assess how policy actors and R-PPs frame REDD+. Section 4 presents our findings on policy actors' views and policy document analysis related to the four questions illustrated above. Finally, the discussion and conclusion reflect on possible consequences of the prominence of storylines for national forest governance, drawing on our findings and existing literature. 


\section{Analytical framework and storylines around REDD+}

This article uses a discursive approach to analyze the framing of REDD+. We draw on Hajer's (1995, p. 44) definition of discourse as "an ensemble of ideas, concepts, and categorizations that are produced, reproduced, and transformed in a particular set of practices and through which meaning is given to physical and social realities". REDD+ discourses matter because they shape policy debates around REDD+ design and justify specific policy design solutions (Den Besten et al., 2014; Hiraldo and Tanner, 2011). Discourse analysis of both spoken and written text-interviews and policy documents - can help to identify which understandings of REDD+ have gained prominence. In this article we draw on a "thin" discursive approach by considering discourses as one of the many important factors that can help identify institutional or political change (see Arts et al. 2010, p. 59 for a distinction between "thick" and "thin" discursive approaches).

Discourse analysis is particularly useful in newly formed policy domains, such as REDD+, as policy actors are confronted with different views when deciding how to operationalize and implement REDD + . It also provides a window into the sociopolitical implications of REDD + , since dominant and institutionalized discourses reveal who has decision-making authority over REDD+, what benefits REDD+ can generate, and for whom.

One way to operationalize discourses is through storylines. A storyline is a narrative that gives meaning to specific phenomena or "through which actors are positioned, and through which specific ideas of 'blame' and 'responsibility' and 'urgency' and 'responsible behavior' are attributed”' (Hajer, 1995, p. 64-65). By referring to a specific element of a storyline, policy actors can signal their position and evoke a storyline or discourse as a whole. We expect prominent storylines to be upheld by key policy actors, while official policy documents, such as R-PPs, can serve as an indication for the institutionalization of prominent storylines (Hajer, 1995; Sharp and Richardson, 2001; Rantala and Di Gregorio, 2014).

In analyzing prominent storylines among policy actors and in the R-PPs of the seven countries, we draw on an expanded version of the analytical framework developed by Vijge (2015). We focus on four inter-related questions: 1) What should REDD+ achieve: carbon or also non-carbon objectives? 2) Who should monitor REDD+ outcomes: only technical experts or also local communities? 3) At what level should REDD+ be governed: at national or sub-national level? and 4) How should REDD+ should be financed: through market or fund-based sources? These four questions were identified through extensive literature reviews as some of the most important scholarly and political debates affecting REDD+ governance (Vijge, 2015; Gupta et al., 2012; Visseren-Hamakers et al., 2012a, b). We analyze four sets of storylines that constitute ranges of answers to the four questions. Table 1 presents specific indicators to assess the prominence of each of these storylines that are used in the rest of the article and are based on the core elements outlined below.

In considering what REDD+ should achieve, we explore views about whether REDD+ is meant to generate carbon benefits alone, or should also generate other, socalled non-carbon or co-benefits such as biodiversity conservation and poverty reduction. Some scholars suggest that REDD+ should primarily be a (cost-)effective climate mitigation option. Others focus on the importance to avoid negative impacts on—or safeguard—non-carbon benefits (see e.g. Arhin, 2014 for an overview). Yet others see great value in REDD+ as a mechanism to also promote the sustainable management of forests or sustainable development more broadly (Chhatre et al., 2012; Levin et al., 2008; McDermott, 2014; Phelps et al., 2012; Nielsen, 2014). We 
analyze three storylines, namely the carbon, safeguards and co-benefits storyline (Table 1). A number of scholars argue that a prime focus on carbon benefits may lead to a "carbonization" of forest governance, where emission reductions become the sole focus of forest management and governance at the expense of non-carbon benefits (Vijge and Gupta, 2014, p. 18; see also Vijge, 2015; Gupta et al., 2012, 2014; Mert, 2009; Stephan, 2012). To assess the framing and planned operationalization of what REDD+ should achieve in the R-PPs, we study which carbon and/or non-carbon objectives will be monitored and how detailed the proposed measuring, reporting and verification (MRV) and/or safeguard information systems are.

In considering who should monitor REDD+ outcomes, many scholarly and political debates focus on the role of technical and local knowledge and the level of participation of local communities in monitoring (see e.g. Vijge, 2015; Gupta et al., 2012; Larrazábal et al., 2012; Danielsen et al., 2011; Nielsen, 2014; Angelsen et al., 2009; Melo et al., 2014). Studies show that high-tech monitoring systems can present trade-offs with community-based monitoring approaches (Murdiyarso et al., 2012). The three storylines that we analyze are: the expert-based, expert-based devolution and the collaboration storyline (Table 1). Due to the centrality of monitoring systems in REDD+ debates, policies and practices, a focus on expert knowledge may empower scientific elites at the cost of those without scientific knowledge or expertise, such as local communities (Gupta et al., 2012, 2014; Den Besten et al., 2014; Buizer et al., 2014; Gupta et al. 2012, 2014). This has also been referred to as a "technicalization" trend (Gupta et al., 2014, p. 182). In considering how debates around this topic resonate in the national policy arena, we assess views among policy actors regarding the authority of scientific experts and the involvement of local communities. We assess evidence from R-PPs on who will be involved in designing and executing MRV systems and whose knowledge is considered important. In doing so, we also consider whether the proposed MRV methods allow for the participation of local communities.

In analyzing at what level REDD+ should be governed, we explore views on the level at which carbon from REDD+ activities should be accounted for. Prominent debates relate to whether REDD+ should be accounted for at the national level to prevent leakage (i.e. displaced emissions) and enable linkages to existing forest policies and programs, or at the sub-national level to allow for context-specific measures (Van der Hoff et al., 2015; Bushley, 2014; Levin et al., 2008). The prime focus of REDD+ accounting activities, funding and REDD+ compensation at the national government level, as well as empirical evidence of REDD + policy processes, has led a number of scholars to assert that REDD+ can lead to a "centralization" of forest governance, and in some cases reverse the long-standing trend of decentralization of forest governance. This could disempower actors operating at the sub-national level, including local communities (Toni, 2011, p. 67; Phelps et al., 2010; Sandbrook et al., 2010; Vijge and Gupta, 2014; Angelsen et al., 2009; Rantala and Di Gregorio, 2014; Buizer et al., 2014). We assess views among policy actors on whether REDD+ accounting and payments should go through the national government. We also assess whether the R-PPs propose a national, sub-national, or nested (i.e. a combination of national and sub-national) approach in establishing reference levels for monitoring forest carbon stock, and whether they envision handling and distributing REDD+ payments at the national, sub-national and/or project level (Table 1).

Finally, in considering how REDD+ should be financed, we focus on whether REDD+ should be market- or fund-based. Some policy advisors and scholars have 
praised REDD + for incentivizing a variety of actors to engage in forest conservation by enabling trade in forest carbon (see e.g. Eliasch, 2008; Stern, 2007). Others, however, criticize the neo-liberal logic of REDD+ and the "marketization" of forest carbon, highlighting the adverse equity and effectiveness implications of turning (certain aspects of) forests into commodities (Melo et al., 2014; Vijge, 2015; Stephan, 2012; Corbera, 2012; Van der Hoff et al., 2015; Nielsen, 2014; Buizer et al., 2014; McAfee, 2012). In this article we analyze views among policy actors regarding the preferred funding mechanism for REDD + . We also analyze visions expressed in the R-PPs regarding what type of finances - market-based, fund-based, or a mix thereof-should be relied on in the long run, and what arrangements are made for the acquisition of such finances (Table 1).

Table 1: Main storylines and indicators around the four questions (source: adapted from Vijge, 2015).

\begin{tabular}{|c|c|c|c|}
\hline \multicolumn{4}{|c|}{ What should REDD+ achieve? } \\
\hline & Carbon storyline & Safeguards storyline & Co-benefits storyline \\
\hline $\begin{array}{l}\text { What are the main } \\
\text { objectives of } \\
\text { REDD+? }\end{array}$ & Carbon benefits & $\begin{array}{l}\text { Carbon benefits, but } \\
\text { safeguarding non- } \\
\text { carbon values }\end{array}$ & $\begin{array}{l}\text { Carbon and non- } \\
\text { carbon benefits }\end{array}$ \\
\hline $\begin{array}{l}\text { Which objectives } \\
\text { will be monitored? }\end{array}$ & $\begin{array}{l}\text { MRV of carbon } \\
\text { benefits }\end{array}$ & $\begin{array}{l}\text { MRV of carbon } \\
\text { benefits and safeguard } \\
\text { information / } \\
\text { monitoring system }\end{array}$ & $\begin{array}{l}\text { MRV of carbon and } \\
\text { non-carbon benefits }\end{array}$ \\
\hline \multicolumn{4}{|c|}{ Who should monitor REDD+ outcomes? } \\
\hline & $\begin{array}{c}\text { Expert-based } \\
\text { storyline }\end{array}$ & $\begin{array}{c}\text { Expert-based } \\
\text { devolution storyline }\end{array}$ & $\begin{array}{c}\text { Collaboration } \\
\text { storyline }\end{array}$ \\
\hline $\begin{array}{l}\text { Who develops MRV } \\
\text { systems, drawing on } \\
\text { whose knowledge? }\end{array}$ & $\begin{array}{l}\text { Technical experts, } \\
\text { using scientific } \\
\text { knowledge }\end{array}$ & $\begin{array}{l}\text { Technical experts, } \\
\text { using scientific } \\
\text { knowledge with } \\
\text { involvement of local } \\
\text { communities }\end{array}$ & $\begin{array}{l}\text { Both technical } \\
\text { experts and local } \\
\text { communities, using } \\
\text { scientific and local } \\
\text { knowledge }\end{array}$ \\
\hline $\begin{array}{l}\text { Who executes MRV } \\
\text { with which } \\
\text { methods? }\end{array}$ & $\begin{array}{l}\text { Technical experts, } \\
\text { using high-tech } \\
\text { methods and on- } \\
\text { the-ground } \\
\text { inventories }\end{array}$ & $\begin{array}{l}\text { Technical experts, } \\
\text { with limited } \\
\text { involvement of local } \\
\text { communities, using } \\
\text { high-tech methods and } \\
\text { participatory on-the- } \\
\text { ground inventories }\end{array}$ & $\begin{array}{l}\text { Both technical } \\
\text { experts and local } \\
\text { communities, using } \\
\text { (among others) } \\
\text { participatory on-the- } \\
\text { ground inventories }\end{array}$ \\
\hline \multicolumn{4}{|c|}{ At what level should REDD+ be governed? } \\
\hline & $\begin{array}{l}\text { National } \\
\text { storyline }\end{array}$ & Nested storyline & $\begin{array}{c}\text { Sub-national } \\
\text { storyline }\end{array}$ \\
\hline $\begin{array}{l}\text { What is the proposed } \\
\text { reference level? }\end{array}$ & National level & $\begin{array}{l}\text { Both national and sub- } \\
\text { national / project level }\end{array}$ & $\begin{array}{l}\text { Sub-national and/or } \\
\text { project level }\end{array}$ \\
\hline $\begin{array}{l}\text { At what level are } \\
\text { REDD+ payments } \\
\text { handled and } \\
\text { distributed? }\end{array}$ & National level & $\begin{array}{l}\text { Payments (eventually) } \\
\text { received at national } \\
\text { level, distributed and } \\
\text { managed at sub- } \\
\text { national / project level }\end{array}$ & $\begin{array}{l}\text { Sub-national and/or } \\
\text { project level }\end{array}$ \\
\hline
\end{tabular}




\begin{tabular}{|l|l|l|l|}
\hline \multicolumn{4}{|c|}{ How should REDD+ be financed? } \\
\hline & $\begin{array}{c}\text { Market-based } \\
\text { storyline }\end{array}$ & \multicolumn{1}{|c|}{ Hybrid storyline } & \multicolumn{1}{c|}{$\begin{array}{c}\text { Fund-based } \\
\text { storyline }\end{array}$} \\
\hline $\begin{array}{l}\text { What is the } \\
\text { envisioned long- } \\
\text { term funding } \\
\text { approach? }\end{array}$ & $\begin{array}{l}\text { Sale of carbon } \\
\text { credits }\end{array}$ & $\begin{array}{l}\text { Sale of carbon credits } \\
\text { and fund-based } \\
\text { finances }\end{array}$ & Fund-based finances \\
\hline $\begin{array}{l}\text { What arrangements } \\
\text { are made for the } \\
\text { acquisition of } \\
\text { funding? }\end{array}$ & $\begin{array}{l}\text { Stimulating } \\
\text { carbon markets }\end{array}$ & $\begin{array}{l}\text { Stimulating both } \\
\text { carbon markets and } \\
\text { fund-raising }\end{array}$ & $\begin{array}{l}\text { Stimulating fund- } \\
\text { raising }\end{array}$ \\
\hline
\end{tabular}

As argued above, an analysis of the prominence of particular storylines around REDD+ can help to assess and explain which design options become dominant and what possible consequences this may have for forest governance. Hence, our analytical framework allows us to draw conclusions on whether the above-described trends of "carbonization", "technicalization", "centralization" and "marketization" of forest governance are likely to occur in any of the seven countries (see section 5).

\section{Research methodology}

The analysis in this article draws on qualitative as well as quantitative research methods. Information about the views of policy actors was derived from national surveys carried out between 2010 and 2013 with representatives of organizations that were relevant for REDD+ decision-making at the national level, including 94 government agencies, 133 non-governmental organizations, 51 businesses, 64 international organizations, 37 research institutes and 9 others not included in the above categories. Each survey covered from 40 to more than 60 policy actors, depending on the size of the country's REDD+ policy domain. Respondents were asked to rate their organization's (rather than personal) level of (dis)agreement with 35 specific position statements, or stances, on REDD+. A likert scale was used to rate their responses, ranging from 1-meaning strongly disagree - to 5-meaning strongly agree (for full information on the surveys, see Brockhaus et al., 2014). Responses to four stances were used to assess, more generally, policy actors' positions related to the four identified questions (Table 2). Note that these are not a perfect reflection of the storylines presented in section 2, but relate to the same four questions discussed in that section. In considering actors' positions on these stances, wherever we refer to powerful actors in this article, we refer to actors that a large number of respondents considered as "especially influential" in shaping national REDD+ policies.

Table 2: Stances used to identify policy actors' positions related to the four questions.

\begin{tabular}{|l|l|}
\hline Four questions & Related stances \\
\hline $\begin{array}{l}\text { What should REDD+ } \\
\text { achieve? }\end{array}$ & $\begin{array}{l}\text { "All REDD schemes aimed at reducing } \mathrm{CO}^{2} \text { emissions } \\
\text { should also require the realization of other key benefits like } \\
\text { poverty reduction and biodiversity conservation". }\end{array}$ \\
\hline $\begin{array}{l}\text { Who should monitor REDD+ } \\
\text { outcomes? }\end{array}$ & $\begin{array}{l}\text { "Scientific experts are the best and final authority on } \\
\text { REDD" }\end{array}$ \\
\hline $\begin{array}{l}\text { At what level should REDD+ } \\
\text { be governed? }\end{array}$ & $\begin{array}{l}\text { "All REDD accounting and payments should go through the } \\
\text { national governments" }\end{array}$ \\
\hline $\begin{array}{l}\text { How should REDD+ be } \\
\text { financed? }\end{array}$ & "REDD schemes should only be financed through funds" \\
\hline
\end{tabular}


We complemented our analysis of the surveys with qualitative observations from semi-structured interviews, which were carried out as a follow-up to the surveys at the same time and with the same policy actors. The surveys and interviews were conducted face-to-face by individual country teams as part of CIFOR's Global Comparative Study on REDD+ (see www.cifor.org/gcs). Relevant organizations were selected on the basis of earlier studies and experience from researchers involved in the Global Comparative Study. Interviews were carried out using a guide with openended questions, and were recorded and transcribed in their entirety (see Brockhaus et al., 2014).

In analyzing the framings of REDD + in each of the countries, we focus on the Readiness Preparation Proposals (R-PPs) that are developed as part of the World Bank's Forest Carbon Partnership Facility (FCPF). The FCPF is one of the largest REDD+ readiness programs. It provides technical and financial support to help countries build their capacity to participate in REDD+ programs and activities. The reason for choosing to analyze R-PPs is that these provide important insights into the direction of national REDD+ strategies and program activities (Angelsen et al., 2009). Moreover, the R-PPs follow a unique format, allowing for systematic comparisons across countries. The seven countries were selected from three continents-Africa, Asia and Latin America - based on their relevance for and early engagement in REDD+. Currently, all seven countries are in the readiness or implementation phase of REDD+ and have finalized their R-PPs (Brockhaus et al., 2014). We draw on additional observations from Emission Reduction Program Idea Notes (ER-PINs) which follow the R-PPs - for the countries within our selection that have developed these: Indonesia, Nepal, Peru and Vietnam. In order to systematically analyze the RPPs, ER-PINs, as well as the semi-structured interviews, the documents and transcripts were coded with the software program NVivo, using the indicators presented in section 2 .

Though the R-PPs have been developed in different years (ranging from 2009 to 2013), we did not find evidence that more recent R-PPs were more advanced or reflected later progress in REDD+ negotiations. Since the surveys were not carried out in the same years as the R-PPs were developed, we do not draw causal links between the views of policy actors and the reflection of storylines in the R-PPs. We recognize that the prominence of views expressed by policy actors does not alone provide an indication of the dominance of issues in national policy dialogues among these actors. Similarly, storylines expressed in the R-PPs may differ from storylines expressed in other REDD+ policy documents, such as national REDD+ strategies. Through reliance on both qualitative and quantitative data from interviews, surveys, policy documents, as well as relevant recent literature, triangulation of data ensured the validity of our research findings (Creswell, 2014). Because of the large diversity among countries in terms of their institutional frameworks as well as the constellations of REDD+ actors, the discussion of this article contains a reflection of the possible consequences of the prominence of storylines, rather than possible explanations of their prominence. 


\section{Results}

This section presents the results of our analysis, structured around our four questions, drawing on national surveys, semi-structured interviews, and the analysis of R-PPs and ER-PINs.

\subsection{What should REDD+ achieve?}

The vast majority of policy actors in the seven countries agreed that REDD+ should also deliver non-carbon benefits such as poverty reduction and biodiversity conservation, while none of the actors strongly disagreed with this (Figure 1). Compared to the other issues we analyzed, co-benefits were most frequently discussed by policy actors in the semi-structured interviews, though the question of how to operationalize these received much less attention and was often left unanswered. In line with this, most R-PPs under study reflect the co-benefits storyline, though there are significant differences in how much importance R-PPs attach to non-carbon benefits (Table 3; Figure 5).

Of the five R-PPs that reflect the co-benefits storyline, Cameroon's R-PP most strongly emphasizes the non-carbon benefits of REDD+. Cameroon's R-PP frames REDD+ as a "development tool that must help the country achieve [its] sustainable development objective" (R-PP Cameroon, 2013, p. 1). To realize this vision, a special unit for "Strategic Environmental and Social Evaluation" should evaluate and monitor the realization of both carbon and non-carbon benefits. REDD+ pilot projects in Cameroon are required to contribute to rather than only safeguard environmental, social and governance co-benefits (see also Dkamela, 2011).

Also the R-PPs of Indonesia, Nepal, Tanzania and Vietnam reflect the cobenefits storyline in their framing of REDD+, though less strongly than Cameroon. These countries frame carbon and non-carbon benefits as equally important (see also Pham et al., 2012). Their R-PPs envision a cross-sectoral approach to integrate their REDD+ strategies with other policies, most notably development and poverty reduction strategies. In terms of their plans to monitor carbon and non-carbon benefits, however, there are significant differences between the four countries.

Nepal's R-PP contains detailed plans to operationalize the unanimous view among Nepalese policy actors that REDD+ should also generate non-carbon benefits (Figure 1). Nepal's R-PP is one of the few which outlines comprehensive baseline studies for non-carbon values and detailed strategies to develop MRV systems both for safeguarding and enhancing non-carbon benefits. Nepal's R-PP frames the World Bank's mandatory Strategic Environmental and Social Assessment (SESA) framework as a tool to achieve Nepal's poverty reduction strategy. In contrast, Vietnam's R-PP largely frames SESA as a framework that enables necessary compliance with World Bank policies to safeguard - rather than also contribute tonon-carbon benefits.

Tanzania's and Indonesia's R-PPs contain the least detailed strategies for measuring, reporting and verifying non-carbon benefits (see also Indrarto et al., 2012; Jagger et al., 2014). Though Tanzania has served as pilot for REDD+ social and environmental standards, neither its R-PP, nor its national REDD+ strategy outline detailed plans to develop safeguards or operationalize non-carbon benefits for REDD+ (Jagger et al., 2014).

The ER-PINs of both Vietnam and Indonesia provide more detailed plans on how to measure non-carbon benefits, listing specific indicators in the mandatory section on social and environmental benefits. Hence, with the development of their ER-PINs, the differences between both countries' proposed non-carbon MRV systems 
have decreased compared to, for instance, Nepal (see also Astuti and McGregor, 2015).

The safeguards storyline is reflected in the R-PPs of Papua New Guinea and Peru. Though Papua New Guinea was the country with the second highest percentage $(96 \%)$ of policy actors agreeing that REDD+ should also generate non-carbon benefits, PNG's R-PP places least emphasis on non-carbon benefits. PNG's R-PP frames REDD+ as an important contribution to " $\mathrm{PNG}$ 's long standing commitment in addressing global climate change" (R-PP PNG, 2013, p. 7). Safeguards are deemed necessary to avoid "endanger[ing] the objectives of REDD+ activities" (p. 63). Plans to develop safeguard policies and a safeguard information system are relatively detailed. PNG's R-PP does not, however, contain a detailed strategy to measure, report and verify non-carbon benefits.

Also Peru's R-PP frames REDD+ primarily as a climate change mitigation option (see also Piu and Menton, 2014; White, 2014). SESA is framed as a means to ensure that "R-PP components have the least possible impact in social and environmental terms" (p. 102). Similarly to PNG's R-PP, while safeguard indicators are identified, an MRV system for non-carbon benefits is not outlined in Peru's R-PP. Despite this, Peru is one of the few countries that mention ideas to promote rather than only monitor and safeguard non-carbon benefits. Hence, while in the framing of objectives Peru's R-PP reflects the safeguards storyline, the planned operationalization of these objectives sits closer to the co-benefits storyline (Figure $5)$.

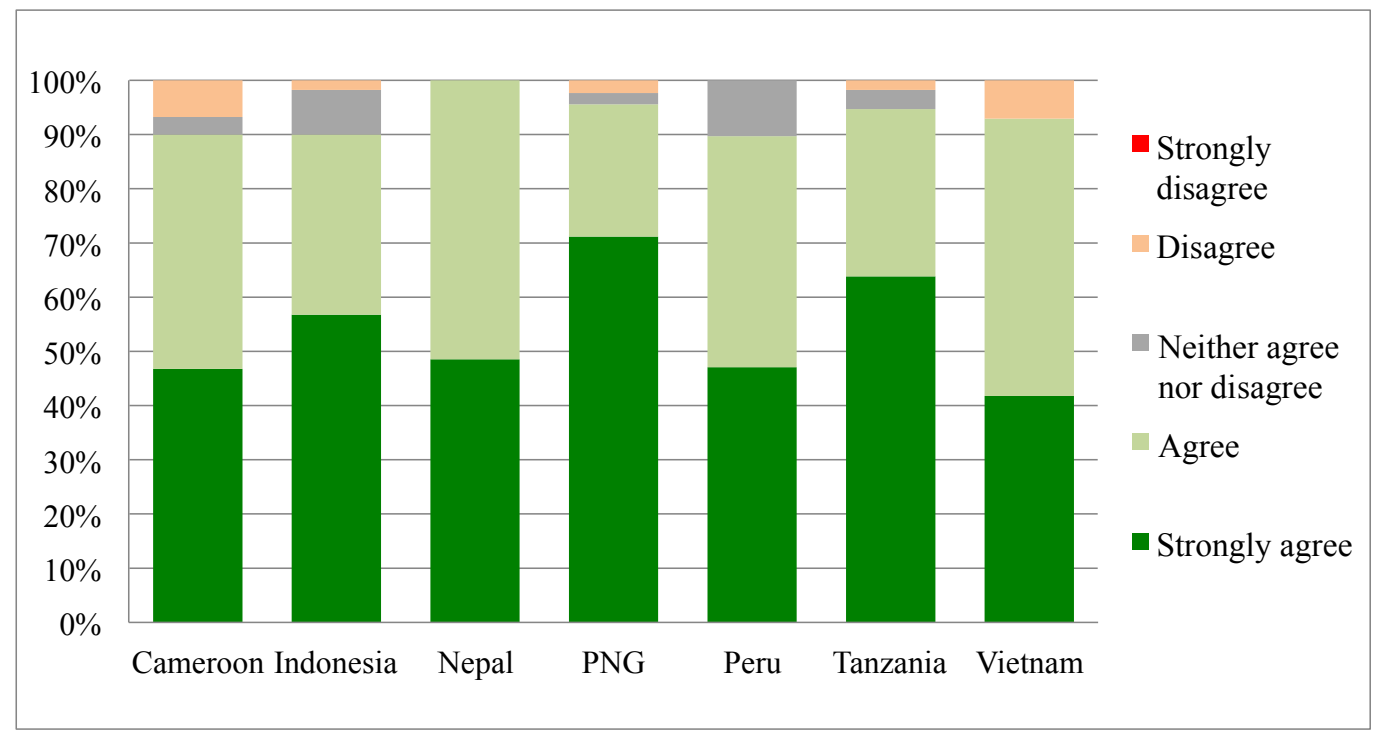

Figure 1: Percentages of policy actors (dis)agreeing with the stance "All REDD schemes aimed at reducing $\mathrm{CO} 2$ emissions should also require the realization of other key benefits like poverty reduction and biodiversity conservation”. 
Table 3: Framing of what REDD+ should achieve in the R-PPs (and ER-PINs).

\begin{tabular}{|c|c|c|}
\hline \multicolumn{3}{|c|}{ What should REDD+ achieve? } \\
\hline & $\begin{array}{l}\text { What are the main objectives of } \\
\text { REDD+? }\end{array}$ & Which objectives will be monitored? \\
\hline Cameroon & $\begin{array}{l}\text { Sustainable development } \rightarrow \\
\text { (Strong) co-benefits storyline }\end{array}$ & $\begin{array}{l}\text { Carbon and non-carbon benefits } \rightarrow \text { Co- } \\
\text { benefits storyline }\end{array}$ \\
\hline Indonesia & $\begin{array}{l}\text { Multiple carbon and non-carbon } \\
\text { benefits } \rightarrow \text { Co-benefits storyline }\end{array}$ & $\begin{array}{l}\text { Not much detail on safeguards or non- } \\
\text { carbon MRV }\end{array}$ \\
\hline Nepal & $\begin{array}{l}\text { Multiple carbon and non-carbon } \\
\text { benefits } \rightarrow \text { Co-benefits storyline }\end{array}$ & $\begin{array}{l}\text { Carbon and non-carbon benefits and } \\
\text { safeguards } \rightarrow \text { Co-benefits storyline }\end{array}$ \\
\hline PNG & $\begin{array}{l}\text { Climate change mitigation } \rightarrow \\
\text { Safeguards storyline }\end{array}$ & $\begin{array}{l}\text { Carbon benefits and safeguards } \rightarrow \\
\text { Safeguards storyline }\end{array}$ \\
\hline Peru & $\begin{array}{l}\text { Climate change mitigation } \rightarrow \\
\text { Safeguards storyline }\end{array}$ & $\begin{array}{l}\text { Carbon benefits and safeguards, ideas to } \\
\text { enhance non-carbon benefits } \rightarrow \\
\text { Safeguards / co-benefits storyline }\end{array}$ \\
\hline Tanzania & $\begin{array}{l}\text { Multiple carbon and non-carbon } \\
\text { benefits } \rightarrow \text { Co-benefits storyline }\end{array}$ & $\begin{array}{l}\text { Not much detail on safeguards or non- } \\
\text { carbon MRV }\end{array}$ \\
\hline Vietnam & $\begin{array}{l}\text { Multiple carbon and non-carbon } \\
\text { benefits } \rightarrow \text { Co-benefits storyline }\end{array}$ & $\begin{array}{l}\text { Carbon benefits and safeguards, non- } \\
\text { carbon policies mentioned } \rightarrow \\
\text { Safequards / co-benefits storyline }\end{array}$ \\
\hline
\end{tabular}

\subsection{Who should monitor REDD+ outcomes?}

Regarding the question who should monitor REDD+ outcomes (only technical experts or also local communities), around half of the policy actors across all countries disagreed with the stance that scientific experts are the best and final authority on REDD+, while around 20\% agreed. Policy actors in Nepal and Tanzania were most strongly united in disagreement that experts are the best and final authority; more than $70 \%$ disagreed in each of these countries (Figure 2). In most countries, the majority of the actors disagreed with the stance, while government agencies - including the most powerful ones - were strongly divided in their views on this.

The collaboration storyline is prominent in most of the countries we analyzed; six of the seven R-PPs outline strategies to involve not only technical experts but also local communities in the execution as well as in the design of REDD+ MRV systems (Figure 5; see also Angelsen et al., 2012). There are, however, significant differences in how far-reaching R-PPs are with regard to involving local communities in proposed MRV systems (Table 4).

Cameroon, Nepal, Peru, Vietnam and, albeit with less detail, Tanzania, all outline plans to establish stakeholder committees to involve non-governmental organizations, community-based organizations, and/or local or indigenous communities in the development of their MRV systems. Peru, Cameroon and Nepal also plan to involve these committees in the development of reference scenarios and non-carbon MRV systems, and intend to draw on local knowledge in developing their REDD+ strategy. In addition, Cameroon, Nepal, Vietnam and, again to a lesser extent, Tanzania, outline plans to develop methods, protocols and/or principles for stakeholder participation in the monitoring of REDD+ outcomes.

Despite the fact that relatively more policy actors in Vietnam agreed with the stance that scientific experts are the best and final authority on REDD+ (Figure 2), Vietnam's R-PP contains the most detailed plans for participatory monitoring. The country plans to develop protocols to allow forest owners to submit data to its national MRV system (see also Pham et al., 2012). Also Nepal seeks to develop a uniform approach to participatory monitoring for REDD+. Nepal's R-PP intends to 
draw on experiences with participatory forest monitoring in existing communitybased forest management systems. Both Nepal and Tanzania have undertaken pilot activities to develop participatory REDD+ MRV methods (see also Pratihast et al., 2013). Cameroon has no such experience (Dkamela, 2011; Pratihast et al., 2013), but envisions a "primary role" for local and indigenous communities in the validation and monitoring of its REDD+ MRV system as well as in the collection of data that will feed into this system (R-PP Cameroon, 2013, p. 97).

Though Peru's R-PP strongly emphasizes community involvement and the use of local knowledge in the design of Peru's national REDD+ MRV system, no plans are outlined for participatory monitoring, not even in the country's ER-PIN (see also White, 2014). The monitoring of non-carbon benefits is said to be "a technical task that will be carried out by institutions specializing in this subject" (R-PP Peru, 2011, p. 130). Hence, while Peru's R-PP reflects the collaboration storyline in the design of its MRV system, it is the only R-PP we analyzed that reflects the expert-based devolution storyline in the planned execution of this system.

Indonesia's R-PP only weakly reflects the collaboration storyline. It states that local and indigenous communities will play an "enormously important role" in the implementation of REDD+, using traditional knowledge as the "basis" for the development of its REDD+ strategy (R-PP Indonesia, 2009, p. 26). However, neither Indonesia's R-PP nor its ER-PIN contain any details on how to involve local communities in MRV design or execution.

The expert-based storyline is reflected only in the R-PP of Papua New Guinea. The country allocates the largest part of its REDD+ funding to the development of an MRV system that is compliant with the good practice guidelines of the Intergovernmental Panel on Climate Change (IPCC), which will be checked by internal and external (UNFCCC) experts. PNG's R-PP does not mention the involvement of local communities in the development of this system. It seeks to "address the safeguards on the full and effective participation of $(\ldots)$ indigenous peoples and local communities" merely through an open access web-portal (R-PP PNG, 2013, p. 100).

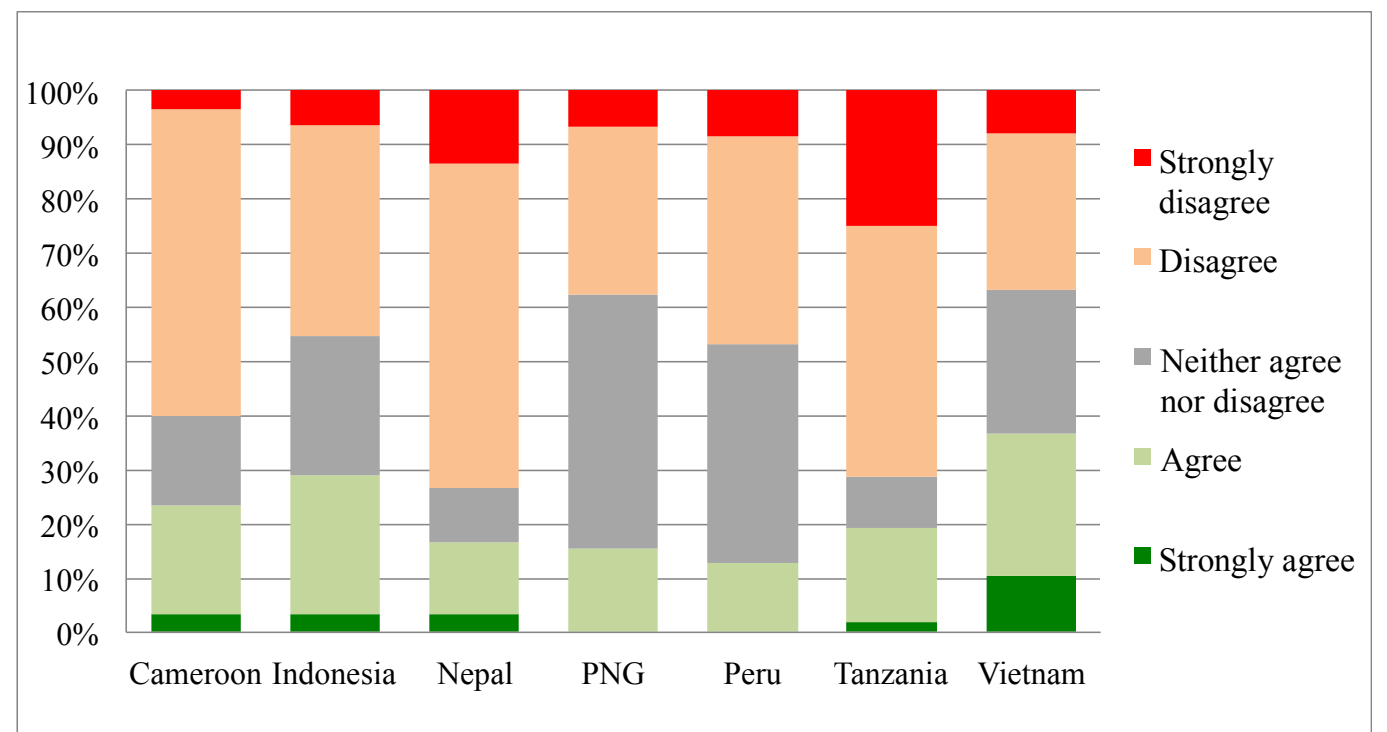

Figure 2: Percentages of national policy actors (dis)agreeing with the stance "Scientific experts are the best and final authority on REDD". 
Table 4: Framing of who should monitor REDD+ in the R-PPs (and ER-PINs).

\begin{tabular}{|c|c|c|}
\hline \multicolumn{3}{|c|}{ Who should monitor REDD+ outcomes? } \\
\hline & $\begin{array}{l}\text { Who develops MRV systems, } \\
\text { drawing on whose knowledge? }\end{array}$ & $\begin{array}{l}\text { Who executes MRV with which } \\
\text { methods? }\end{array}$ \\
\hline Cameroon & $\begin{array}{l}\text { Stakeholder committees to develop } \\
\text { (carbon and non-carbon) MRV, also } \\
\text { drawing on local knowledge } \rightarrow \\
\text { Collaboration storyline }\end{array}$ & $\begin{array}{l}\text { Local communities may supplement } \\
\text { data for national carbon accounting } \\
\text { system } \rightarrow \text { Collaboration storyline }\end{array}$ \\
\hline Indonesia & $\begin{array}{l}\text { No details on proposed stakeholder } \\
\text { participation for MRV development } \\
\rightarrow \text { (Weak) collaboration storyline }\end{array}$ & $\begin{array}{l}\text { Participatory MRV to be encouraged, } \\
\text { but no details } \rightarrow \text { (Weak) } \\
\text { collaboration storyline }\end{array}$ \\
\hline Nepal & $\begin{array}{l}\text { Stakeholder committees to develop } \\
\text { (carbon and non-carbon) MRV, also } \\
\text { drawing on local knowledge } \rightarrow \\
\text { Collaboration storyline }\end{array}$ & $\begin{array}{l}\text { Uniform approach for participatory } \\
\text { monitoring, drawing on experience } \\
\text { with participatory methods } \rightarrow \\
\text { Collaboration storyline }\end{array}$ \\
\hline PNG & $\begin{array}{l}\text { Experts, drawing on IPCC } \\
\text { guidelines. No mention of } \\
\text { community involvement } \rightarrow \text { Expert- } \\
\text { based storyline }\end{array}$ & $\begin{array}{l}\text { Experts, drawing on IPCC } \\
\text { guidelines. No strategy to involve } \\
\text { local communities } \rightarrow \text { Expert-based } \\
\text { storyline }\end{array}$ \\
\hline Peru & $\begin{array}{l}\text { Stakeholder committees to develop } \\
\text { (carbon and non-carbon) MRV, also } \\
\text { drawing on local knowledge } \rightarrow \\
\text { Collaboration storyline }\end{array}$ & $\begin{array}{l}\text { No details on participatory } \\
\text { monitoring } \rightarrow \text { Expert-based } \\
\text { devolution storyline }\end{array}$ \\
\hline Tanzania & $\begin{array}{l}\text { Technical support group to develop } \\
\text { MRV includes community-based } \\
\text { organizations } \rightarrow \text { (Weak) } \\
\text { collaboration storyline }\end{array}$ & $\begin{array}{l}\text { No details on participatory } \\
\text { monitoring, yet pilot activities } \\
\text { undertaken } \rightarrow \text { (Weak) collaboration } \\
\text { storyline }\end{array}$ \\
\hline Vietnam & $\begin{array}{l}\text { Stakeholder committees to develop } \\
\text { MRV } \rightarrow \text { Collaboration storyline }\end{array}$ & $\begin{array}{l}\text { Detailed strategy to develop } \\
\text { protocols for forest owners to submit } \\
\text { data to national MRV system } \rightarrow \\
\text { Collaboration storyline }\end{array}$ \\
\hline
\end{tabular}

\subsection{At what level should REDD+ be governed?}

Views regarding the level at which REDD+ should be governed (national or subnational) were the most divergent compared to the other stances, both within and across countries (Figure 3). Also government agencies within countries were strongly divided on this issue. Though many R-PPs fail to outline full-fledged plans for REDD+ accounting and payment distribution (see also Angelsen et al., 2012), all countries make at least some reference to sub-national accounting. Almost all R-PPs exemplify elements of the nested storyline in their proposed reference levels. However, most countries advocating a nested approach envision a long-term transition to national accounting and assume that REDD+ payments will be handled at and distributed through the national level (Table 5; see also Pham et al., 2013).

The national storyline is particularly prominent in Cameroon, Indonesia, PNG and Tanzania in their plans to handle and distribute REDD+ payments (Figure 5). This is salient given that more policy actors in these countries disagreed than agreed with the stance that REDD+ accounting and payments should go through the national government (Figure 3). Cameroon's R-PP states that "the State will play an essential role in the management of carbon credits at the national level" (R-PP Cameroon, 2013, p. 74), but does not provide much detail on this issue (see also Pham et al., 2013). Also Indonesia's R-PP (albeit with few details) and ER-PIN envision a national registry and payment distribution mechanism. According to PNG's R-PP, a 
national board of directors will provide guidelines and goals for benefit distribution and allocate funds to sub-national entities. In Tanzania, the most powerful government actors were in favor of a national system for REDD+ accounting (see also Rantala and Di Gregorio, 2014). In line with this, Tanzania (again without much detail) plans to develop a national REDD+ trust fund with possibility for direct payments to individuals (see also Angelsen et al., 2012; Pham et al., 2013).

A combination of the national and nested storyline is reflected in the R-PPs of Indonesia, Papua New Guinea and Tanzania in their proposed reference levels (Figure 5). Though plans for building national reference levels are outlined, none of these countries provides details on how to develop the envisioned sub-national reference levels. Both PNG's and Tanzania's R-PPs mention national and sub-national reference levels, but no details are provided on how sub-national reference levels may feed into the proposed national carbon accounting systems. Indonesia aims to be an example country for the nested approach, yet its R-PP only mentions the development of a national carbon accounting system with sub-national reference levels "wherever needed" (R-PP Indonesia, 2009, p. 36).

The nested storyline is reflected in the R-PPs of Nepal, Peru and Vietnam in their plans to develop reference levels as well as - in the case of Peru and Vietnamin their plans to handle and distribute REDD+ payments. Nepal's R-PP plans to develop a monitoring and reporting system to integrate national, regional, district and management unit levels, and the country's ER-PIN outlines several sub-national reference levels. According to Nepal's R-PP and ER-PIN, the most appropriate level for payment distribution is yet to be determined (see also Pham et al., 2013).

Vietnam's R-PP and ER-PIN plan to develop sub-national reference levels based on eco-regions, yet aim to eventually transition to a national accounting system. Vietnam also plans (albeit without much detail) a distribution mechanism whereby the national government will receive and distribute REDD+ payments to provincial and later also to district funds, which in turn will "receive, manage, and make use" of these payments (ER-PIN Vietnam, 2014, p. 33; see also Pham et al., 2013).

The nested storyline is most strongly reflected in Peru's R-PP, which even contains elements of the sub-national storyline. This is salient given that some of the most powerful actors in Peru agreed that REDD+ payments should go through the national government. Peru calls itself a "pioneer in proposing a nested approach" (RPP Peru, 2011, p. 84). Peru's national reference scenario will be developed in line with its decentralization process, through aggregation of regional reference scenarios. These will be built in collaboration with regional REDD+ roundtables, taking account of "the unique background and features of each region" (p. 109). Though REDD+ reporting in Peru will be done nationally, separate accounting of emission reductions should be possible at all levels. Peru's R-PP even states that "the future international rules of the REDD+ mechanism should permit the accounting of sub-national emissions and not make access to international incentives by sub-national initiatives dependent on reductions of national emissions" (R-PP Peru, 2011, p. 99). Peru's ERPIN, however, states that in the long run, benefits will be channeled through a single national fund.

Important to note is that the level at which REDD+ payments are distributed does not necessarily determine which actors will receive REDD+ benefits. Most RPPs, even the ones that envision a national distribution mechanism, acknowledge that REDD+ benefits need to be allocated to local people who live in REDD+ project areas. In developing benefit-sharing mechanisms, for example, Indonesia, Nepal, Tanzania and Vietnam plan to draw on experiences with community-based forest 
management, or - in the case of Indonesia - with community-based benefit-sharing in the country's poverty reduction strategy.

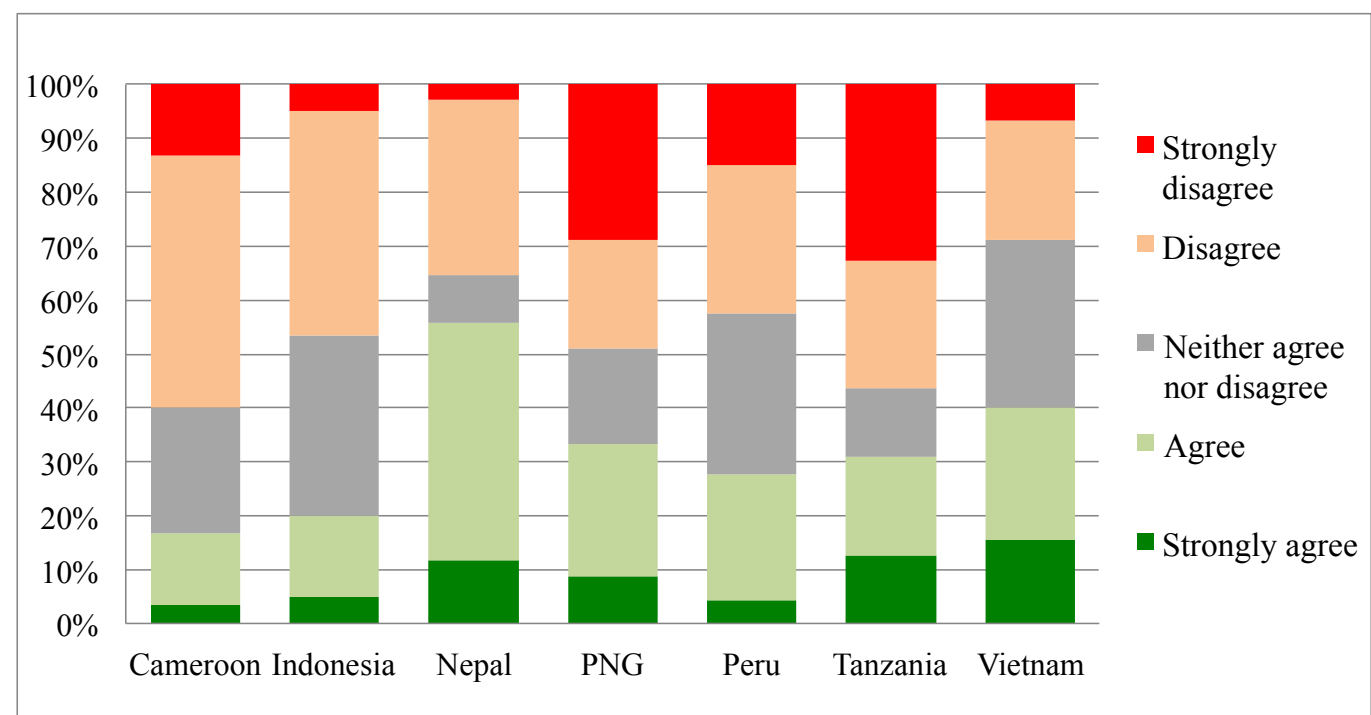

Figure 3: Percentages of national policy actors (dis)agreeing with the stance "All REDD accounting and payments should go through the national governments".

Table 5: Framing of the level at which REDD+ should be governed in the R-PPs (and ER-PINs).

\begin{tabular}{|l|l|l|}
\hline \multicolumn{3}{|c|}{ At what level should REDD+ be governed? } \\
\hline & $\begin{array}{l}\text { What is the proposed reference } \\
\text { level? }\end{array}$ & $\begin{array}{l}\text { At what level are REDD+ payments } \\
\text { handled and distributed? }\end{array}$ \\
\hline Cameroon & Not much detail & $\begin{array}{l}\text { National level, but not much detail } \rightarrow \\
\text { (Weak) national storyline }\end{array}$ \\
\hline Indonesia & $\begin{array}{l}\text { National level, sub-national where } \\
\text { needed } \rightarrow \text { (Weak) national / } \\
\text { nested storyline }\end{array}$ & $\begin{array}{l}\text { National level, but not yet fully } \\
\text { developed } \rightarrow \text { (Weak) national storyline }\end{array}$ \\
\hline Nepal & $\begin{array}{l}\text { Nested approach } \rightarrow \text { Nested } \\
\text { storyline }\end{array}$ & To be determined \\
\hline PNG & $\begin{array}{l}\text { Not much detail on sub-national } \\
\text { level, transition to national level } \\
\rightarrow \text { National / nested storyline }\end{array}$ & $\begin{array}{l}\text { National level with stakeholder } \\
\text { participation } \rightarrow \text { National storyline }\end{array}$ \\
\hline Peru & $\begin{array}{l}\text { Nested approach, transition to } \\
\text { national level } \rightarrow \text { Nested storyline }\end{array}$ & $\begin{array}{l}\text { Sub-national and project level, transition } \\
\text { to national level } \rightarrow \text { Nested / sub- } \\
\text { national storyline }\end{array}$ \\
\hline Tanzania & $\begin{array}{l}\text { National level, sub-national level } \\
\text { mentioned without much detail } \rightarrow \\
\text { (Weak) national / nested } \\
\text { storyline }\end{array}$ & $\begin{array}{l}\text { Envisions national REDD+ trust fund, } \\
\text { but not much detail } \rightarrow \text { (Weak) national } \\
\text { storyline }\end{array}$ \\
\hline Vietnam & $\begin{array}{l}\text { Project level, transition to national } \\
\text { level } \rightarrow \text { Nested storyline }\end{array}$ & $\begin{array}{l}\text { National level, payments managed at } \\
\text { provincial (and district) level } \rightarrow \text { (Weak) } \\
\text { nested storyline }\end{array}$ \\
\hline
\end{tabular}




\subsection{How should REDD+ be financed?}

Views among policy actors regarding how REDD+ should be financed (market-based or fund-based) were strongly divided, both within and between countries. While in Nepal more than $70 \%$ of the actors - including most government agencies - agreed that REDD+ should only be financed through funds, in Cameroon, Indonesia and Peru nearly $60 \%$ of the actors disagreed with this stance (Figure 4 ). Also government agencies within most countries were strongly divided in their answers to this stance. Interestingly, semi-structured interviews revealed virtually no discussion among policy actors of how to acquire market- or fund-based REDD+ finances. Interviewees were more concerned with how to use and allocate REDD+ payments than with how to obtain them. This question is also given scant attention in the R-PPs. While some R-PPs make reference to sources of funding, most R-PPs do not contain a clear vision, let alone a strategy, on how to secure REDD+ financing in the long run. The ER-PINs of the four countries we analyzed provide little more detail. Despite the fact that more than $30 \%$ of the policy actors across the seven countries agreed that REDD+ should only be financed through funds, none of the countries' R-PPs envision or plan to prepare for a REDD+ mechanism that is entirely fund-based. Most R-PPs reflect the market-based storyline by implicitly or explicitly referring to a market-based REDD+ mechanism (Table 6; Figure 5).

The countries with the strongest vision on how to finance REDD+_-PNG and most notably Peru - both envision and prepare for a market-based REDD+ mechanism. Peru's R-PP takes an "approach that promotes public and private investment in forest carbon trade" (R-PP Peru, 2011, p. 11), and aims to reduce market uncertainties that may prevent such investments. It also states that most of Peru's early REDD+ initiatives are flexible enough to become part of a "possible future regulated market" (p. 74). Peru's ER-PIN even considers developing a national carbon market and envisions a market-based approach to facilitate the generation of non-carbon benefits. Similar to Peru, PNG intends to participate in a UNFCCC compliance carbon market with participation of the private sector. The country plans to revise its current land tenure system to support this envisioned market-based approach to REDD+ (see also Babon and Gowae, 2013).

Also Indonesia, Nepal and Tanzania (though weakly) reflect the market-based storyline in their plans to prepare for REDD+ (see also Indrarto et al., 2012). Their RPPs mention measures such as exploring potential carbon markets, enhancing confidence and credibility in the international carbon market, and developing and reviewing legislation and institutional frameworks for forest carbon trade. None of these countries' R-PPs or ER-PINs, however, provide much detail on such measures.

As Figure 4 shows, Cameroon was the country with the highest percentage of policy actors disagreeing that REDD+ should only be financed through funds. Cameroon's R-PP is the only one that (though weakly) reflects the hybrid storyline by preparing for both market- and fund-based finances. Cameroon's R-PP mentions the need to mobilize expertise not only on carbon markets, but also on the procedures of donors and fund-raising. According to Dkamela (2011), however, Cameroon does envision a long-term transition to the carbon market. 


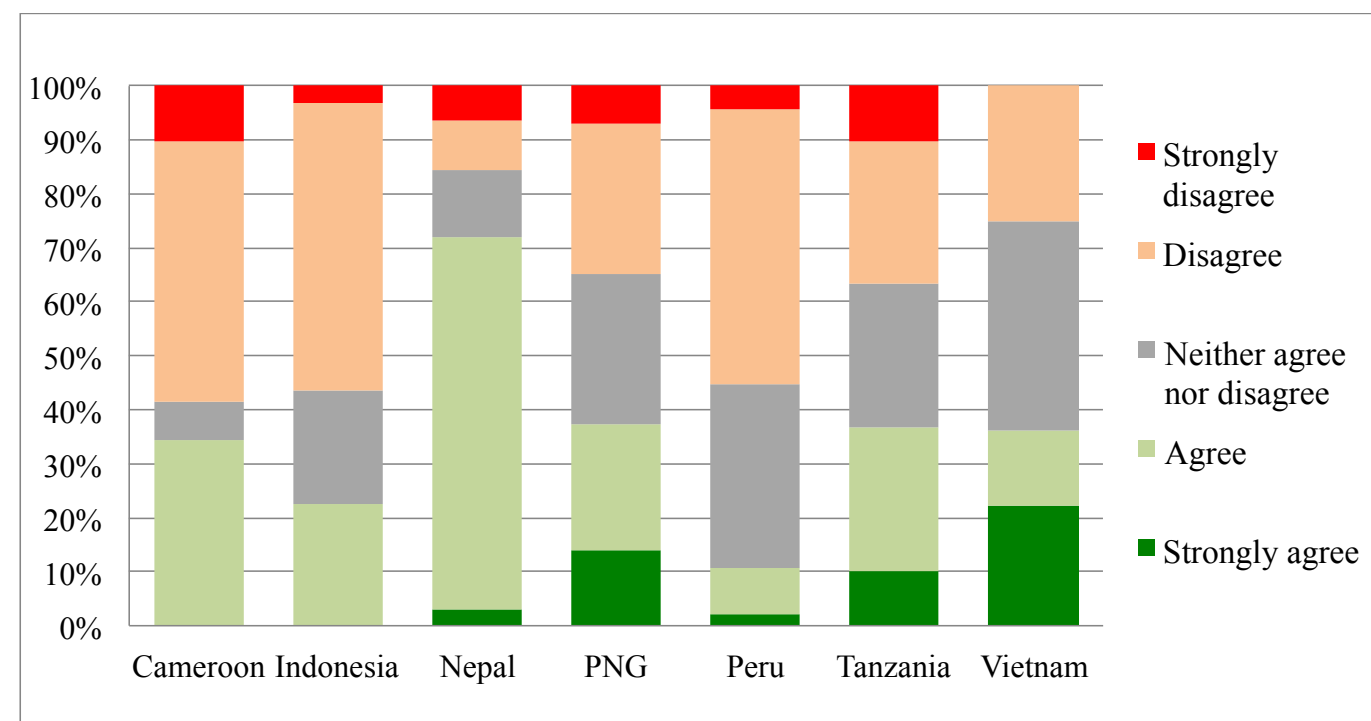

Figure 1: Percentages of national policy actors (dis)agreeing with the stance "REDD schemes should only be financed through funds".

Table 6: Framing of how REDD+ should be financed in the R-PPs (and ER-PINs).

\begin{tabular}{|c|c|c|}
\hline \multicolumn{3}{|c|}{ How should REDD+ be financed? } \\
\hline & $\begin{array}{l}\text { What is the envisioned } \\
\text { long-term funding } \\
\text { approach? }\end{array}$ & $\begin{array}{l}\text { What arrangements are made for the } \\
\text { acquisition of funding? }\end{array}$ \\
\hline Cameroon & Not explicit & $\begin{array}{l}\text { Understand donors' procedures, promote } \\
\text { fund-raising, mobilize expertise on carbon } \\
\text { markets, but not much detail } \rightarrow \text { (Weak) } \\
\text { hybrid storyline }\end{array}$ \\
\hline Indonesia & Not explicit & $\begin{array}{l}\text { Enhance confidence in carbon markets and } \\
\text { explore potential markets, but not much } \\
\text { detail } \rightarrow \text { (Weak) market-based storyline }\end{array}$ \\
\hline Nepal & Not explicit & $\begin{array}{l}\text { Make REDD }+ \text { more sellable and develop } \\
\text { forest carbon trade legislation, but not much } \\
\text { detail } \rightarrow \text { (Weak) market-based storyline }\end{array}$ \\
\hline PNG & $\begin{array}{l}\text { Compliance carbon market } \\
\rightarrow \text { Market-based storyline }\end{array}$ & $\begin{array}{l}\text { Comply with standards of compliance } \\
\text { market } \rightarrow \text { Market-based storyline }\end{array}$ \\
\hline Peru & $\begin{array}{l}\text { Regulated carbon market } \rightarrow \\
\text { (Strong) market-based } \\
\text { storyline }\end{array}$ & $\begin{array}{l}\text { Eliminate market barriers (R-PP), enable } \\
\text { diversified carbon prices (ER-PIN) } \rightarrow \\
\text { (Strong) market-based storyline }\end{array}$ \\
\hline Tanzania & Not explicit & $\begin{array}{l}\text { Review frameworks for and build capacity } \\
\text { on carbon markets, but not much detail } \rightarrow \\
\text { (Weak) market-based storyline }\end{array}$ \\
\hline Vietnam & No vision & No details \\
\hline
\end{tabular}



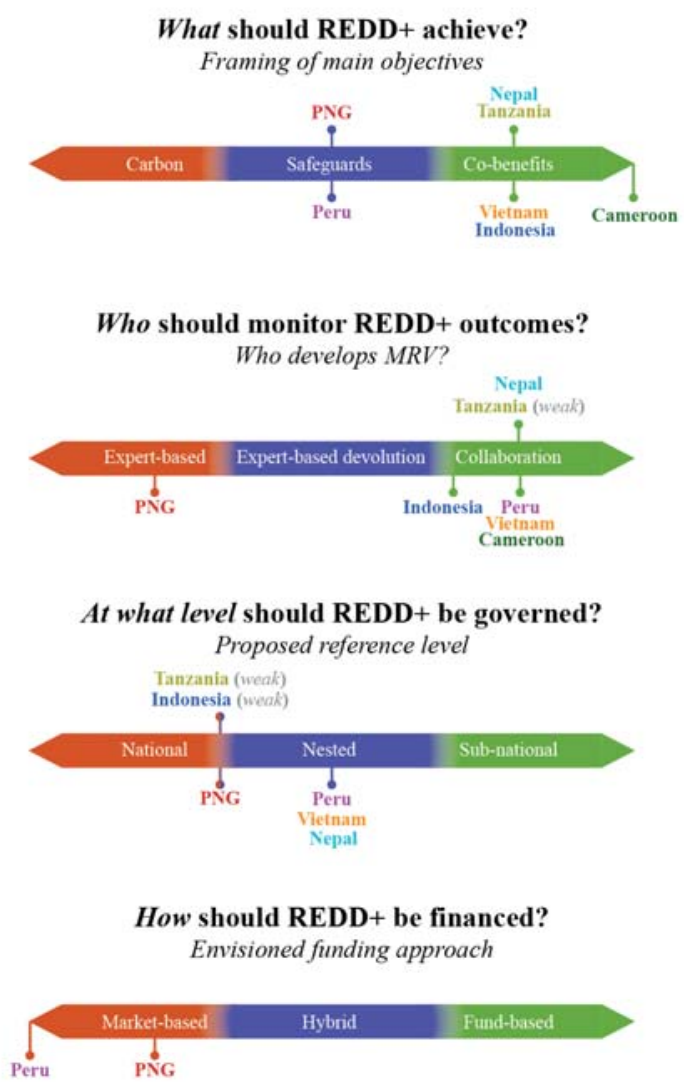
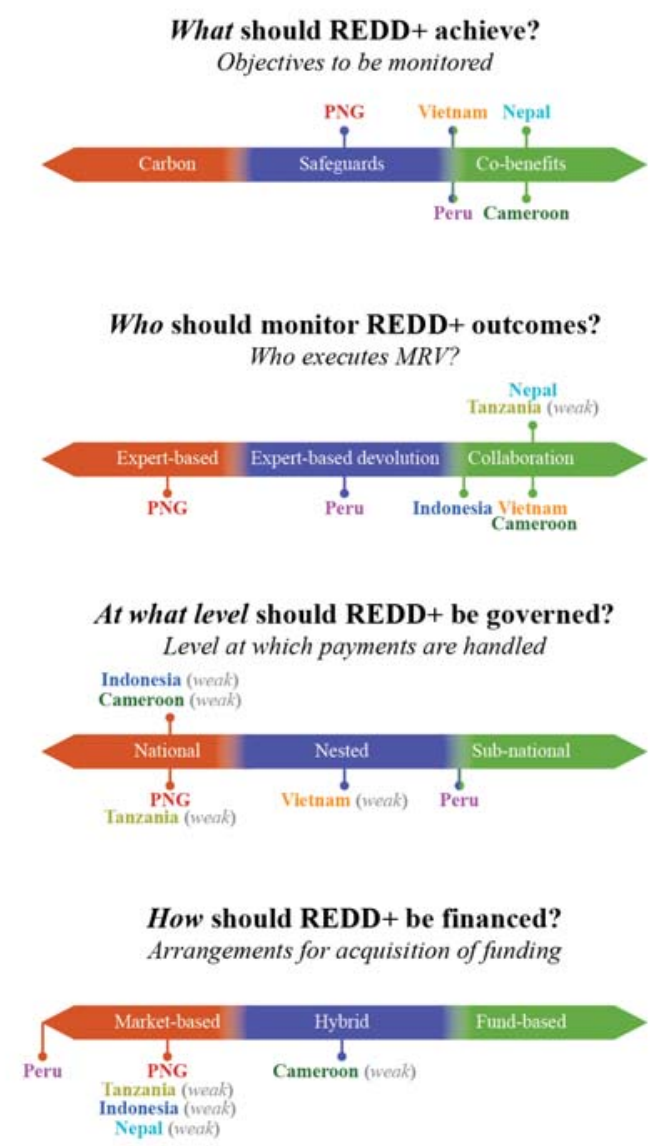

How should REDD+ be financed? Arrangements for acquisition of funding

Figure 5: Overview of storylines reflected in the R-PPs, distinguishing between the two indicators per question identified in section 2. N.B. the R-PPs of those countries that are missing in the figure did not provide sufficient detail to determine which storyline these reflected.

\section{Discussion}

What are the possible consequences of the prominence of different REDD+ storylines for national forest governance in the seven countries? We try to answer this question by assessing the likelihood that REDD+ stimulates the earlier-mentioned "carbonization", "technicalization", "centralization" and "marketization" of forest governance, based on the results discussed above and existing literature.

As to whether REDD+ may lead to a carbonization of forest governance, the large agreement among policy actors and references in R-PPs that REDD+ should also realize non-carbon benefits such as poverty reduction and biodiversity conservation would suggest otherwise. However, of the seven countries, only Cameroon and Nepal outline relatively detailed plans to monitor non-carbon benefits, while few policy actors paid attention to this issue (see also Davis and Daviet 2010 for similar observations in other countries). Without monitoring, ensuring co-benefits might remain an exclusively rhetorical statement, especially since what is being monitored largely determines what is taken into account (Gupta et al., 2012). Most REDD+ countries have a rather limited capacity to monitor environmental and social (non-carbon) benefits and safeguards (Angelsen et al., 2012; Jagger et al., 2014). Hence, a carbonization of forest governance remains a possibility in the five countries that did not outline plans to develop systems to monitor non-carbon benefits. This 
could lead to the disregard of non-carbon benefits. Our analysis also suggests, however, that countries in later stages of REDD+ readiness, such as Vietnam and Indonesia, made progress toward developing more detailed plans for non-carbon and safeguard monitoring systems.

With regard to whether REDD+ may stimulate a technicalization of forest governance, all R-PPs, except PNG's, contain plans to involve local communities in the execution and/or design of REDD+ MRV systems. Some literature, however, suggests that technical aspects of MRV systems dominate national REDD+ policy developments, which inhibits local participation, even in countries with a long history of community-based forestry such as Nepal (Bushley and Khatri, 2013; Paudel and Karki, 2014; Astuti and McGregor, 2015). Additionally, plans to involve local communities in REDD+ monitoring do not necessarily translate into an operationalization of community-based monitoring in national REDD+ MRV systems (Vijge and Gupta, 2014; Skutsch et al., 2014; Paudel et al., 2013; Ojha et al., 2013; Pham et al., 2012). Though some countries have experience with community-based monitoring, this has not been nested effectively within national level MRV systems in any one country (Pratihast et al., 2013). Further analyses of current and planned institutional arrangements would therefore be needed to assess whether the plans for community-based monitoring in six of the seven countries we analyzed are likely to be implemented.

Our analysis showed that REDD+ might lead to a centralization of forest governance, even for countries that plan to make use of national as well as subnational reference levels. The nested approach is predominantly considered as an interim solution in the process toward a national accounting system (see also Rantala and Di Gregorio, 2014; Angelsen et al., 2009). Most countries require REDD+ payments to be handled at and distributed through the national level. Related to this, a study of 32 REDD+ readiness proposals shows that countries structurally fail to discuss how local institutions could play a role in REDD+ benefit distribution (Williams, 2013). Even in Peru, the country that most strongly advocates the nested approach, weak governance capacity at the sub-national level poses significant challenges to the implementation of a decentralized or nested approach to REDD+ (Piu and Menton, 2014; White, 2014). Such challenges have also been identified in the case of Indonesia, PNG, Tanzania, Vietnam and even Nepal with its long history of decentralized forest governance (Kashwan, 2015; Babon and Gowae, 2013; Murdiyarso et al., 2012; Jagger et al., 2014; Bushley, 2014; Pham et al., 2013).

Finally, whether REDD+ stimulates a marketization of forest governance remains to be seen. While most countries implicitly or explicitly assume a marketbased REDD+ mechanism, only two of the R-PPs we analyzed clearly indicate what type of REDD+ funding they envision. The R-PPs contain scant consideration of how to prepare for acquisition of such funding. Minang et al. (2014) similarly show that there is very little progress on REDD+ financing mechanisms in REDD+ readiness processes in Cameroon, Indonesia, Peru and Vietnam. Our analysis of the semistructured interviews also revealed that only few policy actors discussed their preferred funding mechanism for REDD+, with virtually no discussion of institutional arrangements to stimulate the acquisition of REDD+ funding. Given that large uncertainty continues to exist in global REDD+ policy debates on the sources of REDD+ funding (Gupta et al., 2015) — even after the Conferences of the Parties to the UNFCCC in 2015 - most countries seem to take a wait-and-see approach to this issue. 


\section{Conclusion}

In emerging policy domains such as REDD+, discourse analyses can provide deep insights into the direction that a particular policy takes and the (possible) consequences of the institutionalization of certain discourses or storylines. Through an analysis of prominent storylines, this article showed that a carbonization of forest governance, whereby non-carbon benefits such as the provision of local livelihoods and biodiversity conservation are disregarded, remains a possibility in the majority of REDD+ countries studied here. That said, our analysis showed that countries in later stages of REDD+ readiness outline more detailed policies for safeguarding or promoting non-carbon values of forests in their ER-PINs. In this regard, the development of effective safeguard plans and monitoring systems remains crucial. Major attention should also be given to the risks of a centralization of forest governance, given the emphasis on accounting and managing REDD+ payments at the national level. This may lead to limited involvement of sub-national state and nonstate actors - including local communities - in the management of forests, which might reduce compliance (Phelps et al., 2010; Sandbrook et al., 2010). In order to avoid this, one way forward could be to focus resources on putting countries' participatory monitoring plans into practice and direct capacity-building efforts to sub-national levels to enable REDD+ accounting at those levels. Well-integrated subnational institutions that take up REDD+ responsibilities beyond what is conceived in the R-PPs need to be developed. This may also help build often neglected linkages between national readiness activities and sub-national demonstration or pilot activities (Peters-Stanley et al., 2013). In order for such activities to be meaningful in the long run, however, countries would do well to develop more specific funding strategies to acquire and prepare for results-based REDD+ payments. 


\section{References}

Angelsen, A., Brockhaus, M., Kanninen, M., Sills, E., Sunderlin, W.D., WertzKanounnikoff, S., (Eds.), 2009. Realising REDD+: National Strategy and Policy Options. Bogor, Indonesia: CIFOR.

Angelsen, A., Brockhaus, M., Sunderlin, W.D., Verchot, L.V., (Eds.), 2012. Analysing REDD+: Challenges and choices. Bogor, Indonesia: CIFOR.

Arhin, A.A., 2014. Safeguards and dangerguards: a framework for unpacking the black Box of safeguards for REDD+. Forest Policy and Economics 45: 24-31.

Arts, B., Appelstrand, M., Kleinschmit, D., Pülzl, H., Vissen-Hamakers, I., 2010. Discourses, actors and instruments in international forest governance. In: Rayner, J., Buck, A., Katila, P., (Eds.), Embracing Complexity: Meeting the Challenges of International Forest Governance. A Global Assessment Report prepared by the Global Forest Expert Panel on the International Forest Regime. International Union of Forest Research Organizations (IUFRO) World Series vol. 28, 57-73.

Astuti, R., McGregor, A., 2015. Governing carbon, transforming forest politics: A case study of Indonesia's REDD+ Task Force. Asia Pacific Viewpoint 56: 2136.

Babon, A., Gowae, G.Y., 2013. The context of REDD+ in Papua New Guinea: Drivers, agents and institutions. Occasional Paper 89. Bogor, Indonesia: CIFOR.

Brockhaus, M., Di Gregorio, M., Carmenta, R., 2014. REDD+ policy networks: exploring actors and power structures in an emerging policy domain. Ecology and Society 19(4): 29.

Buizer, M., Humphreys, D., De Jong, W., 2014. Climate change and deforestation: the evolution of an intersecting policy domain. Environmental Science and Policy 35: 1-11.

Bushley, B.R., 2014. REDD+ policy making in Nepal: toward state-centric, polycentric, or market-oriented governance. Ecology and Society 19(3): 34 .

Bushley, B.R., Khatri, D.B., 2013. REDD+ Policymaking \& Forest Governance in Nepal: A Policy Network Analysis of Organizations Involved in REDD+ Activities, Policy Processes and Events. Final report of a collaborative study by ForestAction Nepal \& CIFOR.

Chhatre, A., Lakhanpal, S., Larson, A.M., Nelson, F., Ojha, H., Rao, J., 2012. Social safeguards and co-benefits in REDD+: a review of the adjacent possible. Current Opinion in Environmental Sustainability 4(6): 654-660.

Corbera, E., 2012. Problematizing REDD+ as an experiment in payments for ecosystem services. Current Opinion in Environmental Sustainability 4(6): 612-619.

Creswell, J.W., 2014. Research design: qualitative, quantitative, and mixed methods approaches (4th edition). California: SAGE publications.

Danielsen, F., Skutsch, M.M., Burgess, N.D., Jensen, P.M., Andrianandrasana, H., Karky, B.S., Lewis, R., Lovett, J.C., Massao, J., Ngaga, Y., Phartiyal, P., Poulsen, M.K., Singh, S.P., Solis, S., Sorensen, M., Tewari, A., Young, R., Zahabu, E., 2011. At the heart of REDD+: a role for local people in monitoring forests? Conservation Letters 00: 1-10.

Davis, C., Daviet, F., 2010. Investing in results: enhancing coordination for more effective interim REDD+ financing. World Resources Institute, Washington, $D C$. 
Den Besten, J.-W., Arts, B., Verkooijen, P., 2014. The evolution of REDD+: An analysis of discursive institutional dynamics. Environmental Science and Policy 35: 40-48.

Di Gregorio, M., Brockhaus, M., Cronin, T., Muharrom, E., Mardiah, S., Santoso, L., 2015. Deadlock or Transformational Change? Exploring Public Discourse on REDD+ Across Seven Countries. Global Environmental Politics 15(4): 63-84.

Dkamela, G.P., 2011. The context of REDD+ in Cameroon: Drivers, agents and institutions. Occasional paper 57. Bogor, Indonesia: CIFOR.

Eliasch, J., 2008. Climate change: financing global forests: the Eliasch review. Earthscan.

ER-PIN Indonesia, 2014, September 5. Forest Carbon Partnership Fund Emission Reductions Program Idea Note (ER-PIN) Form. Indonesia District Level REDD+ ER Program. http://www.forestcarbonpartnership.org/readiness-fund. Last accessed 16 February 2015.

ER-PIN Nepal, 2014, March 7. Forest Carbon Partnership Fund Emission Reductions Program Idea Note (ER-PIN) Form. People and Forests-An SMF-based Emission Reduction Program in Nepal's Terai Arc Landscape. http://www.forestcarbonpartnership.org/readiness-fund. Last accessed 16 February 2015.

ER-PIN Peru, 2014, September 12. Forest Carbon Partnership Fund Emission Reductions Program Idea Note (ER-PIN) Form. Emission Reductions in the Peruvian Amazon. http://www.forestcarbonpartnership.org/readiness-fund. Last accessed 16 February 2015.

ER-PIN Vietnam, 2014, May 26. Forest Carbon Partnership Fund Emission Reductions Program Idea Note (ER-PIN) Form. Sustainable management of forests through low emissions development planning for green growth in the North central agro-ecological region. http://www.forestcarbonpartnership.org/readiness-fund. Last accessed 16 February 2015.

Gupta, A., Lövbrand, E., Turnhout, E., Vijge, M.J., 2012. In pursuit of carbon accountability: the politics of REDD+ measuring, reporting and verification systems. Current Opinion in Environmental Sustainability 4(6): 726-731.

Gupta, A., Pistorius, T., Vijge, M.J., 2015. Managing Institutional Complexity: The REDD+ Partnership as Bridge Institution? International Environmental Agreements: Politics, Law and Economics, 1-20.

Gupta, A., Vijge, M.J., Turnhout, E., Pistorius, T., 2014. Making REDD+ transparent: the politics of measuring, reporting and verification systems. In: Gupta, A., Mason, M., (Eds.), Transparency in Global Environmental Governance. MIT Press, 181-201.

Gupta, J., Van der Grijp, N., Kuik, O., (Eds.), 2013. Climate change, forests and REDD: Lessons for institutional design. London: Routledge.

Hajer, M.A., 1995. The Politics of Environmental Discourse: Ecological Modernization and the Policy. Oxford: Clarendon Press.

Hiraldo, R., Tanner, T., 2011. Forest Voices: Competing Narratives over REDD. IDS Bulletin 42(3): 42-51.

Indrarto, G.B., Murharjanti, P., Khatarina, J., Pulungan, I., Ivalerina, F., Rahman, J., Prana, M.N., Resosudarmo, I.A.P., Muharrom, E., 2012. The Context of REDD+ in Indonesia: Drivers, agents and institutions. Working Paper 92. Bogor, Indonesia: CIFOR. 
Jagger, P., Brockhaus, M., Duchelle, A.E., Gebara, M.F., Lawlor, K., Resosudarmo, I. A.P., Sunderlin, W.D., 2014. Multi-level policy dialogues, processes, and actions: Challenges and opportunities for national REDD+ safeguards measurement, reporting, and verification (MRV). Forests 5(9): 2136-2162.

Kashwan, P., 2015. Forest Policy, Institutions, and REDD+ in India, Tanzania, and Mexico. Global Environmental Politics 15 (3): 95-117.

Larrazábal, A., McCall, M.K., Mwampamba, T.H., Skutsch, M., 2012. The role of community carbon monitoring for REDD+: a review of experiences. Current Opinion in Environmental Sustainability 4(6): 707-716.

Levin, K., McDermott, C., Cashore, B., 2008. The climate regime as global forest governance: can Reduced Emissions from Deforestation and Forest Degradation (REDD) initiatives pass a 'dual effectiveness' test? International Forestry Review 10(3): 538-549.

McAfee, K., 2012. The contradictory logic of global ecosystem services markets. Development and Change 43(1): 105-131.

McDermott, C.L., 2014. REDDuced: from sustainability to legality to units of carbon-the search for common interests in international forest governance. Environmental Science and Policy 35: 12-19.

Melo, I., Turnhout, E., Arts, B., 2014. Integrating multiple benefits in market-based climate mitigation schemes: the case of the climate, community and biodiversity certification scheme. Environmental Science and Policy 35: 4956.

Mert, A., 2009. Partnerships for sustainable development as discursive practice: shifts in discourses of environment and democracy. Forest Policy and Economics 11 (5-6): 326-339.

Minang, P. A., Van Noordwijk, M., Duguma, L. A., Alemagi, D., Do, T. H., Bernard, F., ... Leimona, B., 2014. REDD+ Readiness progress across countries: Time for reconsideration. Climate policy 14(6): 685-708.

Murdiyarso, D., Brockhaus, M., Sunderlin, W. D., Verchot, L., 2012. Some lessons learned from the first generation of REDD+ activities. Current Opinion in Environmental Sustainability 4(6): 678-685.

Nielsen, T.D., 2014. The role of discourses in governing forests to combat climate change. International Environmental Agreements 14: 265-280.

Ojha, H.R., Khatri, D., Shrestha, K.K., Bushley, B.R., Sharma, N., 2013. Carbon, community and governance: is Nepal getting ready for REDD+? Forests, Trees and Livelihoods 22(4): 216-229.

Paudel, N.S., Karki, R., 2014. REDD+ readiness in Nepal: In search of effective stakeholder participation. Infobrief Vol. 74. Bogor, Indonesia: CIFOR.

Paudel, N.S., Khatri, D.B., Khanal, D.R. and Karki, R., 2013. The context of REDD+ in Nepal: Drivers, agents and institutions. Occasional Paper 81. Bogor, Indonesia: CIFOR.

Peters-Stanley, M., Gonzalez, G., Yin, D., Goldstein, A., \& Hamrick, K. (2013). Covering new ground: state of the forest carbon markets 2013. Forest Trends' Ecosystem Marketplace, Washington DC, 80.

Pham, T.T., Brockhaus, M., Wong, G., Dung, L.N., Tjajadi, J.S., Loft, L., Luttrell C. and Assembe Mvondo, S., 2013. Approaches to benefit sharing: A preliminary comparative analysis of 13 REDD+ countries. Working Paper 108. Bogor, Indonesia: CIFOR. 
Pham, T.T., Moeliono, M., Nguyen, T.H., Nguyen, H.T., Vu, T.H., 2012. The context of REDD+ in Vietnam: Drivers, agents and institutions. Occasional Paper 75. Bogor, Indonesia: CIFOR.

Phelps, J., Friess, D.A., Webb, E.L., 2012. Win-win REDD+ approaches belie carbon-biodiversity trade-offs. Biological Conservation 154: 53-60.

Phelps, J., Webb, E.L., Agrawal, A., 2010. Does REDD+ threaten to recentralize forest governance? Science 328: 312-313.

Pistorius, T., Schaich, H., Winkel, G., Plieninger, T., Bieling, C., Konold, W., Volz, K.R., 2012. Lessons for REDDplus: a comparative analysis of the German discourse on forest functions and the global ecosystem services debate. Forest Policy and Economics 18: 4-12.

Piu, H.C., Menton, M., 2014. The context of REDD+ in Peru: Drivers, agents and institutions. Occasional Paper 106. Bogor, Indonesia: CIFOR.

Pratihast, A. K., Herold, M., De Sy, V., Murdiyarso, D., Skutsch, M., 2013. Linking community-based and national REDD+ monitoring: A review of the potential. Carbon Management 4(1): 91-104.

R-PP Annexes Tanzania, 2010, October. Forest Carbon Partnership Fund Readiness Preparation Proposal (R-PP) Form. http://www.forestcarbonpartnership.org/readiness-fund. Last accessed 14 October 2014.

R-PP Cameroon, 2013, January. Forest Carbon Partnership Fund Readiness Preparation Proposal (R-PP) Form. http://www.forestcarbonpartnership.org/readiness-fund. Last accessed 14 October 2014.

R-PP Indonesia, 2009, May. Forest Carbon Partnership Fund Readiness Preparation Proposal (R-PP) Form. http://www.forestcarbonpartnership.org/readinessfund. Last accessed 14 October 2014.

R-PP Nepal, 2010, September 5. Forest Carbon Partnership Fund Readiness Preparation Proposal (R-PP) Form. http://www.forestcarbonpartnership.org/readiness-fund. Last accessed 14 October 2014.

R-PP Peru, 2011, March 7. Forest Carbon Partnership Fund Readiness Preparation Proposal (R-PP) Form. http://www.forestcarbonpartnership.org/readinessfund. Last accessed 14 October 2014.

R-PP PNG, 2013, December 9. Forest Carbon Partnership Fund Readiness Preparation Proposal (R-PP) Form. http://www.forestcarbonpartnership.org/readiness-fund. Last accessed 14 October 2014.

R-PP Tanzania, 2010, October. Forest Carbon Partnership Fund Readiness Preparation Proposal (R-PP) Form. http://www.forestcarbonpartnership.org/readiness-fund. Last accessed 14 October 2014.

R-PP Vietnam, 2011, November 18. Forest Carbon Partnership Fund Readiness Preparation Proposal (R-PP) Form. http://www.forestcarbonpartnership.org/readiness-fund. Last accessed 14 October 2014.

Rantala, S., Di Gregorio, M., 2014. Multistakeholder environmental governance in action: REDD+ discourse coalitions in Tanzania. Ecology and Society 19(2): 66. 
Sandbrook, C., Nelson, F., Adams, W., Agrawal, A., 2010. Carbon, forests and the REDD paradox. Fauna \& Flora International. Oryx 44(3): 330-334.

Sharp, L., Richardson, T., 2001. Reflections on Foucauldian discourse analysis in planning and environmental policy research. Journal of Environmental Policy and Planning 3: 193-209.

Skutsch, M., Turnhout, E., Vijge, M.J., Herold, M., Wits, T., den Besten, J.-W., Torres, A.B., 2014. Options for a national framework for benefit distribution and their relation to community-based and national REDD+ monitoring. Forests 5(7): 1596-1617.

Stephan, B., 2012. Bringing discourse to the market: the commodification of avoided deforestation. Environmental Politics 21(4): 621-639.

Stern, N., 2007. The Economics of Climate Change. The Stern Review. Cambridge University Press, Cambridge, MA.

Toni, F., 2011. Decentralization and REDD+ in Brazil. Forests 2: 66-85.

Van der Hoff, R., Rajão, R., Leroy, P., Boezeman, D., 2015. The parallel materialization of REDD+ implementation discourses in Brazil. Forest Policy and Economics 55: 37-45.

Vijge, M.J., 2015. Competing discourses on REDD+: Global debates versus the first Indian REDD+ project. Forest Policy and Economics 56: 38-47.

Vijge, M.J., Gupta, A., 2014. Framing REDD+ in India: Carbonizing and Centralizing Indian Forest Governance? Environmental Science and Policy 38: 17-27.

Visseren-Hamakers, I.J., McDermott, C., Vijge, M.J., Cashore, B., 2012a. Trade-offs, co-benefits and safeguards: current debates on the breadth of REDD+. Current Opinion in Environmental Sustainability 4(6): 646-653.

Visseren-Hamakers, I.J., Gupta, A., Herold, M., Peña-Claros, M., Vijge, M.J., 2012b. Will REDD+ work? The need for interdisciplinary research to address key challenges. Current Opinion on Environmental Sustainability 4(6): 590-596.

White, D., 2014. A perfect storm? Indigenous rights within a national REDD+ readiness process in Peru. Mitigation and adaptation strategies for global change 19(6): 657-676.

Williams, L.G., 2013. Putting the pieces together for good governance of REDD+: an analysis of 32 REDD + country readiness proposals. Washington DC, USA: World Resources Institute. 